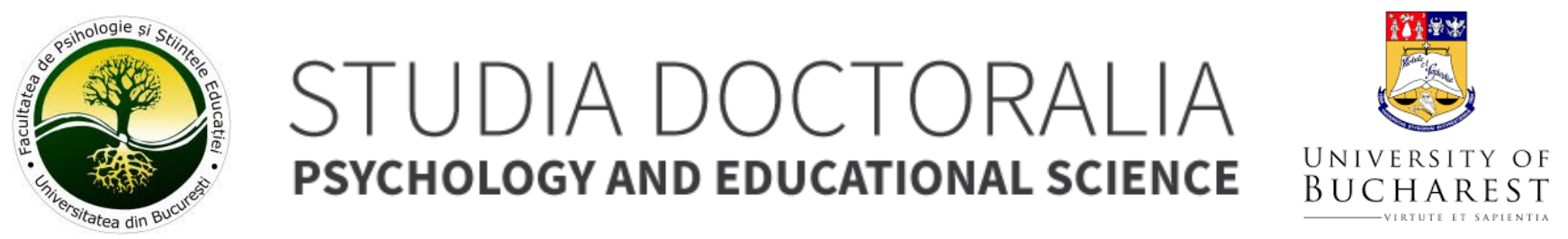

\title{
Dark Triad, Risk Taking and Counterproductive Work Behavior in Different Organizational Contexts
}

\author{
Ana Alexandra Stoica
}

University of Bucharest

\section{ARTICLE INFO}

Article history:

Received 11-March-2021

Accepted 30-Aprilt-2021

Available online 01-May-2021

This article should be cited as: Stoica, A. A.. (2021). Dark Triad, Risk Taking and Counterproductive Work Behavior in Different Organizational Contexts. Studia Doctoralia. Psychology and Educational Science, 12(1), 4-19. https://doi.org/10.47040/sd0000085

This is an open access article under the CC BY license (http://creativecommons.org/licenses/by/4.0/).

University of Bucharest, Department of Psychology, 90 Panduri Av, Bucharest, RO.

Tel.: +40 (0) 31-425.34.45

E-mail address: stoica_ana_alexandra@yahoo.com

\section{ABSTRACT}

The purpose of this study is to analyze the relationship between Dark Triad of Personality, risk-taking and counterproductive work behaviort. The study involved 200 people aged between 18 and 51 years, $M=27.69, S D=$ 9.83 , of which 35 are males (17.5\%) and 165 are females (82.5\%). The instruments used were The Dirty Dozen: A Concise Measure of the Dark Triad (Jonason \& Webster, 2010), Counterproductive Work Behavior Checklist - CWBC (Spector, Bauer \& Fox, 2010) and RISK-TAKING [JPI: Risk Taking [Rkt] (Goldberg et. al, 2006). The results showed that people who work in non-profit organizations (volunteers), those who have a low seniority in work or who hold a leadership position tend to take more risks than others. Low seniority at work also correlates with counterproductive behaviors. In contrast, no significant difference was observed as far as the other two demographic characteristics are concerned. Moreover, the results show that Machiavellianism is responsible for $16 \%$ of the variation of counterproductive work behavior, and risk-taking mediates this relatonship. Narcissism and psychopathy are responsible for $10 \%$ and $13 \%$ respectively of the variation of this behavior, the mediation percentage of risk taking being $19.2 \%$ concerning the first one and $22.4 \%$ concerning psychopathy. Given these results, the study can be useful in the organizational field, providing employers with more data that they can take into account when recruiting staff. It can also be helpful when it comes to better employee management, as well as a deeper understanding behind counterproductive behaviors, thus leading more easily to diminishing them.

Keywords: Dark Triad, counterproductive work behavior, risk-taking 


\section{INTRODUCTION}

\section{Dark Triad}

The concept of "Dark Triad" was introduced by (Paulhus \& Williams, 2002), being composed of three undesirable clinical behaviors: narcissism, Machiavellianism and psychopathy. Over time, they have proven to be more than the cardinal traits of the negative characters in movies, famous criminals and manic leaders. Studies in this area help us understand the darker side of the personality, as well as how these traits are often encountered in ordinary people (Paulhus, 2014). These three characteristics are associated with a number of maladaptive outcomes, such as interpersonal difficulties or atypical moral judgments (Muris et al., 2017), involving tendencies to manipulate and exploit others for self-interest (Jonason et al., 2010).

Narcissism is characterized by a continuous need for admiration and attention, grandeur. For this type of person, social interactions are a scene where they can expose their strengths, manipulating the people around them so that their superiority can be proven (Morf \& Rhodewalt, 2001). Despite the fact that narcissistic people are generally seen as arrogant, aggressive, self-centered and always seeking attention from others (Seidman, 2013), narcissism can be considered a healthy and natural part of our personality and mental development (Bender, 2012). For example, it is positively associated with well-being and extraversion, but negatively associated with depression, sadness, loneliness, and neuroticism (Miller \& Campbell, 2008). Due to their high scores of extraversion and self-esteem, they are likely to stand out in groups and crowds (DeWall et al., 2011), being often in leadership positions (Nevicka et al., 2011). When a narcissistic person is in this position, he is evaluated by those around him as very effective, even if he is not (Nevicka et al., 2018). Previous studies show that they overestimate both their performance (Farwell \& Wohlwend-Lloyd, 1998) and their potential to be leaders (Judge et al., 2006). Moreover, they also tend to overestimate their level of physical attractiveness (Buffardi \& Campbell, 2008) and intelligence (Gabriel et al., 1994), amplifying their qualities (Paulhus, 1998).

Machiavellianism refers to people who lack empathy and who tend to strategically manipulate those around them, being positively associated with counterproductive behaviors (DeShong et al., 2015). This type of person tends to choose friends who are, in their opinion, easier to exploit (Jonason \& Schmitt, 2012). Moreover, they are characterized by emotional detachment, cynical worldview, pragmatic beliefs, manipulation, and long-term strategic planning to pursue their own goals (Rauthmann \& Will, 2011). Machiavellian people can strategically adopt desirable behaviors in order to be put in a good light. They want to create the impression that they are employees dedicated to work, impressing people with influence (Zettler
\& Solga, 2013). They easily manage to form a good opinion and highlight their qualities (Bolino \& Turnley, 2003) because they are adaptive, adjusting their behavior according to the context. Thus, it is easier for them to be pleasant and to manipulate the people around them (RuizPalomino \& Linuesa-Langreo, 2018). However, several studies confirm that Machiavellianism is negatively correlated with agreeableness and conscientiousness, being positively correlated with neuroticism instead (Jonason et al., 2010; Veselka et al., 2012).

Last but not least, psychopathy includes traits related to impulsivity, emotional coldness, and insensitivity, which lead to antisocial behaviors (Nguyen et al., 2021). Unlike the first two, which leave a good impression on those around them, people who have psychopathy as a personality trait are not so appreciated, being impulsive and disrespectful from the beginning. Because of these characteristics, as well as disagreement with others, irresponsibility and low level of empathy, they are seen by society as negative role models (Rauthmann, 2012). The Dark Triad, especially psychopathy, is associated with immoral behaviors such as lying (Brewer et al., 2019), cheating (Alavi et al., 2018), sexual violence (Zeigler-Hill et al., 2016), animal violence (Kavanagh et al., 2013), racism (Daniel N. Jones, 2013a) and other minor or major forms of crime (Chabrol et al., 2017). Although the specific features of psychopathy can be found in the general population, most studies in this field have been conducted on prisoners and criminals with mental disorders (Board \& Fritzon, 2005). In some contexts psychopathy is an important predictor of criminal behavior and especially of violence (Hart \& Hare, 1997), being positively correlated with recidivism, conditional release failure, and poor treatment response (Hemphill et al., 1998).

Despite the undesirable behaviors found, some recent studies suggest that accentuated personality traits may also have adaptive components in certain areas. These may be associated with men's short-term success in finding a partner (Jonason et al., 2009). Narcissism can lead to a better wage and even a leadership position (Jonason et al., 2018), the subordinates of these people benefiting, in turn, from promotions and salary increases (Volmer et al., 2016).

\section{Counterproductive work behavior (CWB)}

One of the central themes studied and addressed in the field of organizational psychology is based on the relationship between different personality traits and behavior at work. Recently, attention has been shifted to a broader area of workplace behaviors, including now counterproductive (Campbell, 1990). These are actions that harm both an organization and its members (O'Boyle et al., 2011). Destroying the organization's property, intentionally performing incorrect work, taking unauthorized breaks, or disseminating confidential company information are just a 
few examples of organization-oriented counterproductive behavior. In parallel, hitting a colleague, insults, gossip or verbal aggression are part of counterproductive behavior towards people (Berry et al., 2007; Cohen, 2016). Thus, Sackett \& DeVore (2002) choose to approach an organizational perspective in defining this type of behavior, considering it contrary to the legitimate interests of an organization. They emphasize intentional behavior, so that, in their view, if the damage is accidental, that conduct does not fall within that definition.

Hollinger and Davis (2001) observed that as a result of employee theft and scams, US traders lose about \$ 40.7 million daily. Also, according to research by Bennett and Robinson (2000), $15 \%$ of employees admitted to stealing from their employers at least once. Moreover, in addition to the amount of money lost annually by companies, this type of behavior has a negative impact on other employees. For example, being the target of such behavior can cause decreased job satisfaction, while increasing stress or the desire to resign (Berry et al., 2012).

\section{Counterproductive work behavior and organization} type

The financial aspect is the major difference between NGOs and for-profit organizations, so this study aims to investigate the behavior of employees and volunteers in terms of material rewards. When the organizations want a good development of their activities and, at the same time, capable employees, they must provide in turn favorable working conditions and satisfactory salaries (Ali \& Akram, 2012). Moreover, according to Lawal et al. (2019), people who are satisfied with the salary received have a low tendency to engage in counterproductive behavior at work. Given these studies, as well as the situation of NGO volunteers, it is very likely that the CWB will be influenced, among other things, by the type of organization.

\section{Counterproductive work behavior and position held in the organization}

Often, in the management positions within an organization are met people who have specific features of the Dark Triad. Narcissists, concerned with demonstrating their superiority, often seek exposure in front of crowds, always wanting to be heard (Morf \& Rhodewalt, 2001). The same is true for people with Machiavellian personality traits, who are often in leadership positions and want to impress through false dedication (Zettler \& Solga, 2013). Following a meta-analysis by O'Boyle et al. (2012) were observed consistent decreases in performance at work in association with psychopathy and Machiavellianism. A high score of all three traits is, according to the study, closely related to CWB. Thus, the present study aims to demonstrate that there is a significant difference in counterproductive work behavior depending on the type of job. People in a leadership position are more likely to engage in such behavior, pursuing only their own interests.

\section{Counterproductive work behavior according to seniority}

Following meta-analytical research, it has been observed that older employees are less likely to engage in counterproductive behavior in the workplace, as opposed to younger ones (Ng \& Feldman, 2008; Pletzer, 2021). One of the reasons this happens may be the change in certain personality traits over time. Ashton and Lee (2016) observed that honesty increases throughout an adult's life, being a feature the stronger the older he is. As the vast majority of people engage in youth (Edmonds \& Shrestha, 2012), seniority in work is directly proportional to age. Thus, it can be stated that seniority in work is closely related to counterproductive behavior, which decreases over time.

\section{Risk taking}

Risk is a controversial element in decision-making (Cox \& Hetzel, 2008). Risk-taking can be defined as behavior that leads to potential danger, while providing the opportunity to obtain a reward (McCleskey \& Gruda, 2020). We can take as an example the situation of a Formula 1 driver, who risks his life reaching far too high speeds in exchange for victory and fame. A more common case is that of drug users, who risk their health, career and family enjoying in return the sensations they have. Figner and Weber (2011) consider that the least pleasant result in risky options is usually worse than in safe options. Similarly, the positive result, which is hoped for, is more pleasant than that of safe options.

People differ considerably depending on their attitude towards risk-taking (Schonberg et al., 2011) as everyone's behavior is related to the different ways in which an individual perceives situations that involve uncertainty. $\mathrm{He}$ is not influenced by the reality of risk, but rather by the way he perceives it (Leather, 2009). Situations may be seen as desirable and therefore worth certain losses, or they may be perceived as undesirable, in which case it is not worth assuming potential losses (Blais \& Weber, 2006). Thus, individuals break down risk behavior into assessing benefits and losses, thus becoming a compromise between perceived benefits and perceived risks. It can be seen that options that represent a higher risk also bring greater benefits (Figner \& Weber, 2011).

According to previous studies, involvement in risktaking is often specific to one of the five main areas: social, recreational, ethical, financial, and health and safety (Stanwix \& Walker, 2021; Wilke et al., 2014). This perspective contributes to a better understanding of why some people may choose to take risks in a particular context, while others do not. For example, a person may engage in recreational risk-taking, such as bungee jumping, but not when there is a financial goal in the middle. Some people believe that the risks taken on the social or recreational level have more advantages, compared to the other three (Stanwix \& Walker, 2021). 
Irwin and Ryan (1989) explain risk-taking among adolescents in terms of the fact that they have limited life experience and do not fully understand the consequences of their actions. In addition, they perceive rather positive results that may occur as a result of their behavior, losing sight of the other option. Thus, what an adolescent considers to have a positive effect can be viewed at the opposite pole through the eyes of an adult (Leather, 2009).

\section{Risk taking and type of organization}

Non-profit organizations and those in the public or private sectors that ultimately have a profit differ from each other in mission and approach. The present study aims to observe the difference between these two entities in terms of risk-taking, taking into account the material rewards received.

Previous research has shown that simply remembering money can affect motivation, thinking and behavior (Vohs, 2015). Another study mentions that a small or even nonexistent amount of money causes employees to take risks, but when the amount is high, they prefer to "go safe", the risk taking decreasing. In an organizational setting when the stakes are higher, people choose to get involved in low-risk projects to make sure they don't lose the amount of money they receive (Sprinkle et al., 2008). Given that money influences risk-taking, but also that a person who is part of a student association, volunteer or NGO, does not receive a sum of money as a result of the effort, it is considered to increase risk-taking among people who are part of such organizations.

\section{Risk taking and position held in the organization}

Unlike gambling individuals who cannot influence how they function in any way, people in leadership tend to believe that their personal talents, as well as the capabilities of their organizations, can greatly affect the success of their risky initiatives (Chatterjee \& Hambrick, 2011). Although they consider that the risk assumed by them is not similar to that of gambling, being questioned the abilities to influence the respective project, still an executive director assumes more risks than a subordinate with an executive function (Shapira, 1995).

Thus, given that decision-making involves taking risks, but also that a manager is forced to make several decisions in terms of his position, the present study aims to demonstrate that people who hold a leadership position have a higher level of risk-taking than those holding an executive position.

\section{Risk taking and seniority}

It can be seen that often the first years of work correspond to the specific years of adolescence and the following years (Sawyer et al., 2018). Moreover, according to Gardner and Steinberg (2005) risk-taking in this period of life is much more pronounced than in adulthood. Although adolescents' ability to make rational decisions and understand risk situations is close to that of adults, they are not yet well enough formed (Fischhoff, 1992).

Given that most people are employed at the age of adolescence, even after the first years of seniority, they will continue to take more risks than older people due to the period of development in which they are situated, as they have not yet reached full psychosocial development (Cauffman \& Steinberg, 2000).

Taking into account these aspects, we formulate the following hypotheses:

$\mathrm{H} 1$ : There are statistically significant differences in risktaking depending on certain socio-demographic variables.

$\mathrm{H} 2$. There are statistically significant differences in counterproductive behavior at work depending on certain socio-demographic variables.

\section{Dark Triad and counterproductive work behavior}

Studies have focused on discovering possible antecedents of counterproductive behavior in the workplace. In recent years, there has been extensive research on employees who exhibited destructive, toxic or abusive behavior (Jonason et al., 2012). According to researchers Wu and Lebreton (2011) deviant behaviors may be the result of deviant personality traits. This reasoning provides a basis for the association between counterproductive behavior in the workplace and the Dark Triad, so that one of the main hypotheses of this study considers the relationship between the two. Thus, the lack of responsibility encountered in psychopathy, the lack of empathy encountered in narcissism but also the lack of morality found in Machiavellianism contribute to the formation of this type of behavior (Jonason et al., 2012).

Although the three traits have different styles and manifestations, their relationship to counterproductive behavior in the workplace is similar, as each contains a set of accentuated negative interpersonal tendencies (O'Boyle et al., 2012). People who have a high score in terms of psychopathy tend to follow their own ineters regardless of whether it, or the means by which it is achieved, harms those around them (Baloch et al., 2017). Regarding Machiavellianism, Moore et al. (2012) consider that people who get a high score on this trait tend to be immoral, being willing to do anything to achieve their goals. Last but not least, narcissistic people will do everything possible for those around them to have a very good opinion about them, exaggerating their qualities (Wu \& Lebreton, 2011). Such an approach, as well as the tendency to make others feel inferior, may increase the possibility for narcissistic people to engage in deviant behavior (Baloch et al., 2017).

Despite these characteristics, it is not surprising that people with personality traits such as narcissism, Machiavellianism and psychopathy are still employed. They embody many desirable traits such as charm, assertiveness, and the ability to manage certain resources (Ames, 2009). 
Taking these into account, we will test if there are significant relationships between Dark Triad traits and counterproductive work behavior:

H3: There is a statistically significant positive relationship between accentuated personality traits and counterproductive work behavior.

\section{Dark Triad and risk-taking}

The features of Dark Triad are correlated with different behaviors that affect human health, they are more impulsive (Jones \& Paulhus, 2011), competitive (Jones \& Figueredo, 2013) and taking more risks (Gott \& Hetzel-Riggin, 2018). According to the literature, two negative personality traits associated with risk-taking are narcissism and psychopathy (Crysel et al., 2013).

Risk-taking in psychopathy is the result of an irregular lifestyle (Hare \& Neumann, 2008). Such people cannot effectively regulate their impulses, thus assuming far too high risks in exchange for minor gains (Jones, 2013b). Similarly, individuals with a high narcissism score may have the illusion of control, tending to be biased when it comes to decision making. This, along with minimizing potential chances of loss, can lead to risky behaviors (Lakey et al., 2008). They tend to move towards risky behaviors in the financial, health and social spheres (Buelow \& Brunell, 2014), taking risks when it comes to investing in the stock market (Foster et al., 2011). Unlike the first two traits, Machiavellianism is not associated with risk-taking (Crysel et al., 2013), except when the possibility of being caught or discovered is very low (Jones, 2013b) or the gains are very high (Azizli et al., 2016).

\section{METHODOLOGY}

\section{Participants and procedure}

The present study involved 200 people aged between 18 and 51 years, $M=27.69, A S=9.83$. Of these, 35 are male (17.5\%) and 165 are female (82.5\%), 80 participants work in non-profit organizations independent institutions in relation to any public authority, operated for a collective benefit, public or social) (40\%), and 120 work in for-profir companies / firms (60\%). Regarding the length of service, 61 participants state that they are between 0-1 years old (30.5\%), 100 are between 1 and 5 years old (50\%), 14 are between 5 and 5 years old. 10 years (7\%), and 25 are between 10 and 20 years old (12.5\%). Regarding the position held, 155 participants hold executive positions (77.5\%), while 45 hold management positions (22.5\%). The design of the study is non-experimental, cross-sectional, correlational and data collection took place over four months, from November, 2020 to February, 2021. The participants were contacted online, through the social platforms Facebook and Instagram. They were then directed

\section{Counterproductive work behavior and risk-taking}

The literature highlights several studies that empirically link counterproductive behavior in the field of work to different personality traits, such as anger (O'Brien \& Allen, 2007), manipulation, egotism and risk-taking (O'Neill \& Hastings, 2011). Moreover, according to them, risk-taking is one of the strongest predictors in relation to workplace deviance. Despite the fact that not much research has been started to shed light on the relationship between the two, they have some common features, such as impulsivity or work performance.

Scherer et al. (2013) conducted a study that showed the importance of impulsivity in predicting counterproductive behavior, placing it under the umbrella of psychopathy. This correlates negatively with conscientiousness (Harpur et al., 1989), approaching rather a disorganized and irresponsible lifestyle.

Regarding the link between impulsivity and risk-taking, Wu and Lebreton (2011) consider that people we encounter this trait are constantly looking for extreme sensations and risk, often finding it difficult to maintain a stable relationship, whether it is related to work or personal life. The impact that impulsivity has on counterproductive behavior in the workplace is not a minor one, which can be neglected, this feature explaining some of the undesirable decisions of employees.

Following all these, we intend to test if risk-teking has a mediating effect in the relationship between Dark Triad traits and counterproductive work behavior:

H4. Risk-taking mediates the relationship between accentuated personality traits and counterproductive work behavior.

to the Google Forms platform, with which the data was collected. Respondents were informed about the confidentiality of the data and the academic purpose of the paper, with the possibility to withdraw from the study if they so wished.

\section{Instruments}

Dark Triad of personality was measured using the Dirty Dozen: A Concise Measure of the Dark Triad (Jonason \& Webster, 2010). The questionnaire contains 12 items and captures three dimensions, each of which has been assigned a number of four items. The dimensions are Machiavellianism, psychopathy and narcissism. The answers are given on a seven-step Likert scale, where $1=$ untrue, $4=$ somewhat true, and $7=$ very true.

Counterproductive work behavior was measured with the Counterproductive Work Behavior Checklist (CWB-C) (Spector, Bauer \& Fox, 2010). The scale is a tool for assessing counterproductive behavior in the workplace and 
consists of 10 items, being translated into Romanian. Answers are given on a five-step Likert scale, where $1=$ never and 5 = daily.

Risk-taking was measured with the Jackson Personality Inventory [JPI-R] Risk Scale (RISK-TAKING [JPI: Risk
Taking [Rkt]) (Goldberg et al., 2006). The questionnaire contains 10 items, and the answer was scored on a five-step Likert scale, where $1=$ never, and $5=$ very often.

\section{RESULTS}

\section{Descriptive statistics.}

Table 1. Average scores, standard deviations, internal consistency coefficients and correlations between variables

\begin{tabular}{|c|c|c|c|c|c|c|c|c|}
\hline & $M$ & AS & $a$ & MAC & PSI & NAR & CWB & RT \\
\hline MAC & 10.36 & 5.21 & .81 & 1 & & & & \\
\hline PSI & 10.06 & 4.29 & .59 & $.56^{\star \star}$ & 1 & & & \\
\hline NAR & 15.67 & 5.37 & .76 & $.43^{\star *}$ & $.27^{\star \star}$ & 1 & & \\
\hline CWB & 16.80 & 5.37 & .80 & $.41^{\star *}$ & $.37^{\star \star}$ & $.31^{\star *}$ & 1 & \\
\hline RT & 24.96 & 6.25 & .76 & $.38^{* *}$ & $.42^{* *}$ & $.24^{* *}$ & $.31^{* *}$ & 1 \\
\hline
\end{tabular}

**. $p<.01$

MAC - Machiavellianism, PSI - Psychopathy, NAR - Narcissism, CWB - Counterproductive work behavior, RT - Risk taking

\section{Hypotheses testing}

$\mathrm{H1}$ : There are statistically significant differences in risktaking depending on certain socio-demographic variables.

H1a: People working in non-profit organizations have a significantly higher level of risk-taking than those in for-profit organizations.

H1b: People with a low seniority have a significantly higher level of risk-taking than those with a long seniority.
H1c: People who hold a management position have a significantly higher level of risk-taking than those who hold an executive position.

In order to test these hypotheses, two independent samples $t$ tests were performed to analyze the differences depending on the type of company and the position held and a one-way analysis of variance ANOVA for the differences according to seniority.

Table 2. Mean scores for risk-taking by type of organization

\begin{tabular}{llrrrr}
\hline & Organization type & $\mathrm{N}$ & $\mathrm{M}$ & $\mathrm{SD}$ & ESM \\
\hline RT & Non-profit & 80 & 26.41 & 5.73 & .64 \\
& Profit & 120 & 23.98 & 6.42 & .59 \\
\hline
\end{tabular}

RT - Risk taking

Table 3. Independent samples t-test for risk-taking by type of organization

\begin{tabular}{|c|c|c|c|c|c|c|c|c|c|c|}
\hline & & \multirow[b]{2}{*}{$\mathrm{F}$} & \multirow[b]{2}{*}{ Sig. } & \multirow[b]{2}{*}{$\mathrm{t}$} & \multirow[b]{2}{*}{$\mathrm{df}$} & \multirow[b]{2}{*}{$p$} & \multirow[b]{2}{*}{ DM } & \multirow[b]{2}{*}{ ESD } & \multicolumn{2}{|c|}{$95 \% \mathrm{Cl}$} \\
\hline & & & & & & & & & Min. & Max. \\
\hline RT & Equality of variance & 1.18 & .28 & 2.74 & 198 & .01 & 2.43 & .89 & .68 & 4.18 \\
\hline
\end{tabular}

It is observed that there are statistically significant differences in terms of risk-taking depending on the type of organization, so that for employees in non-profit organizations $M=26.41, A S=5.73$, while for employees in for profit organizations $M=23.98, S D=6.42$. The difference is statistically significant, $t(198)=2.74, \mathrm{Cl} 95 \%(.68,4.18), \mathrm{p}$ $<.05$, the effect size being $d=.40$.

Table 4. One-way ANOVA for risk-taking by seniority

\begin{tabular}{|c|c|c|c|c|c|}
\hline & Sum of Squares & df & Mean of Squares & $\mathrm{F}$ & Sig. \\
\hline Between groups & 370.43 & 3 & 123.48 & 3.27 & .02 \\
\hline Within groups & 7402.16 & 196 & 37.77 & & \\
\hline Total & 7772.60 & 199 & & & \\
\hline
\end{tabular}


Table 5. Multiple comparisons Bonferroni test for risk-taking by seniority

\begin{tabular}{llrrrrrr}
\hline & & & & \multicolumn{3}{c}{$95 \% \mathrm{Cl}$} \\
(I) Seniority in work & (J) Seniority in work & DM (I-J) & ES & Sig. & Min. & \multicolumn{2}{c}{ Max. } \\
\hline 0-1 years & 10-20 years & $4.33^{*}$ & 1.46 & .02 & .44 & 8.22 \\
\hline
\end{tabular}

It is observed that there are statistically significant differences in terms of risk-taking depending on seniority, the most visible being between those with 0-1 years experience and those with 10-20 years. The difference of the means is statistically significant, DM $=4.33, \mathrm{Cl} 95 \%$ (44, 8.22), $p<0.5$.

Table 6. Mean scores for risk-taking by position in organization

\begin{tabular}{llrrrr}
\hline & Position & N & M & SD & \\
\hline RT & Executive & 155 & 24.39 & 6.32 & ESM \\
& Managerial & 45 & 26.91 & 5.63 & .84 \\
\hline
\end{tabular}

RT - Risk taking

Table 7. Independent samples t- test for risk-taking by position in organization

\begin{tabular}{rrrrrrrrrr}
\hline & & & & & & \multicolumn{3}{c}{$95 \% \mathrm{Cl}$} & \multicolumn{3}{c}{ DM } & ESD & Min. & Max. \\
\hline Equality of Variance & 1.83 & .18 & -2.41 & 198 & .017 & -2.52 & 1.05 & -4.59 & -.46 \\
\hline
\end{tabular}

It is observed that there are statistically significant differences in terms of risk-taking depending on the position held, so that for employees holding an executive position $M$ $=24.39$, AS $=6.32$, while for employees holding $\mathrm{a}$ management position $M=26.91, A S=5.63$. The difference is statistically significant, $\mathrm{t}(198)=-2.41, \mathrm{Cl} 95 \%$ (- 4.59, $.46), p<.05$, the effect size being $d=.42$.

$\mathrm{H} 2$ : There are statistically significant differences in counterproductive work behavior depending on certain socio-demographic variables.

H2a: People who work in non-profit organizations have a significantly higher level of counterproductive work behavior than those in for-profit organizations.
$\mathrm{H} 2 \mathrm{~b}$ : People with a short work experience have a significantly higher level of counterproductive work behavior than those with a long work experience.

$\mathrm{H} 2 \mathrm{c}$ : People in a managerial position have a significantly higher level of counterproductive work behavior than those in an executive position.

In order to test these hypotheses, two independent samples $t$ tests were performed to analyze the differences depending on the type of company and the position held and a one-way analysis of variance ANOVA for the differences according to seniority.

Table 8. Mean scores for counterproductive work behavior by type of organization

\begin{tabular}{llrrrr}
\hline & Organization type & $\mathrm{N}$ & $\mathrm{M}$ & $\mathrm{SD}$ & ESM \\
\hline CWB & Non-profit & 80 & 17.40 & 5.88 & .66 \\
& Profit & 120 & 16.40 & 4.99 & .46 \\
\hline
\end{tabular}

CWB - Counterproductive work behavior

Table 9. Independent samplest-test for counterproductive work behavior by type of organization

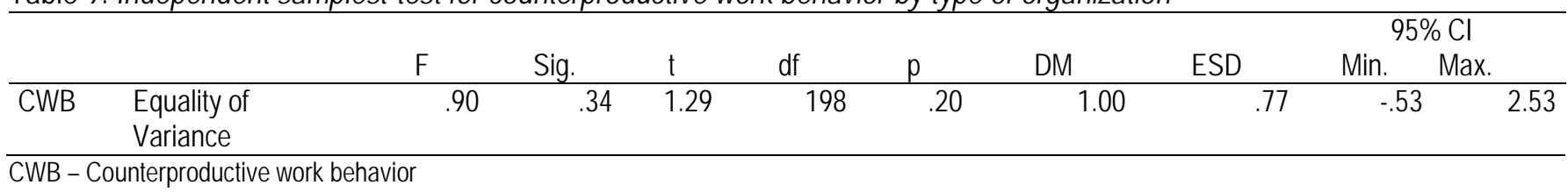

It is observed that there are no statistically significant differences in terms of counterproductive work behavior depending on the type of organization, so that for employees in non-profit organizations $M=17.40, A S=5.88$, while for employees profit $\mathrm{M}=16.40, \mathrm{SD}=4.99$. The difference is not significant, t (198) $=1.29, \mathrm{Cl} 95 \%(-.53,2.53), \mathrm{p}>.05$, the effect size being $d=.18$. 
Table 10. One-way ANOVA for counterproductive work behavior by seniority

\begin{tabular}{lrrrrr}
\hline & Suma of Squares & $\mathrm{df}$ & Mean of Squares & $\mathrm{F}$ & Sig. \\
\hline Between groups & 289.86 & 3 & 96.62 & 3.47 & \\
Within groups & 5452.14 & 196 & 27.82 & & \\
Total & 5742.00 & 199 & & \\
\hline
\end{tabular}

It is observed that there are statistically significant differences in terms of counterproductive work behavior depending on seniority, $F(3,196)=3.47, p<.05$. Thus, the lowest score is registered by employees with an experience of 1-5 years, $M=17.98, A S=5.76$, the group being followed by those with an experience between $0-1$ years, $M=15.84$, AS $=4.91$, then the employees with work experience of 5 -
10 years, $M=15.71, A S=4.53$ and finally, the group with a work experience of 10-20 years, $M=15.04$, AS $=4.33$. However, the Bonferroni post-hoc test for multiple comparisons does not reveal significant differences between specific seniority groups. Although no such difference is concretely observed, it exists in general, $F(3$, 196) $=3.47, p<.05$.

Table 11. Mean scores for counterproductive work behavior by position

\begin{tabular}{llrrrr}
\hline & Position & $\mathrm{N}$ & $\mathrm{M}$ & AS & ESM \\
\hline CWB & Executive & 155 & 16.53 & 5.02 & .40 \\
& Managerial & 45 & 17.73 & 6.41 & .96 \\
\hline
\end{tabular}

CWB - Counterproductive work behavior

Table 12. Independent samples t-test for counterproductive work behavior by position in organization

\begin{tabular}{|c|c|c|c|c|c|c|c|c|c|c|}
\hline & & \multirow[b]{2}{*}{$F$} & \multirow[b]{2}{*}{ Sig. } & \multirow[b]{2}{*}{$t$} & \multirow[b]{2}{*}{$\mathrm{df}$} & \multirow[b]{2}{*}{$p$} & \multirow[b]{2}{*}{ DM } & \multirow[b]{2}{*}{ ESD } & \multicolumn{2}{|c|}{$95 \% \mathrm{Cl}$} \\
\hline & & & & & & & & & Min. & Max. \\
\hline CWB & $\begin{array}{l}\text { Equality of } \\
\text { Variance }\end{array}$ & 2.77 & .10 & -1.33 & 198 & .19 & -1.20 & .91 & -3.00 & .59 \\
\hline
\end{tabular}

It is observed that there are no statistically significant differences in counterproductive work behavior according to the position held, so that for employees with an executive function $M=16.53, A S=5.02$, while for employees with managerial function $M=17.73, A S=6.41$. The difference is not significant, $t(198)=-1.33, \mathrm{Cl} 95 \%(-3.00, .59), \mathrm{p}>.05$, the effect size being $d=.21$.
H3: There is a statistically significant positive relationship between accentuated personality traits and counterproductive work behavior.

In order to test this hypothesis, three simple linear regression analyzes were performed, having as predictors, alternatively, the three dimensions of the Dark Triad (Machiavellianism, narcissism and psychopathy) and as a dependent variable, counterproductivework behavior.

Table 13. Linear regression analyses for Dark Triad traits and counterproductive work behavior

\begin{tabular}{llllllll}
\hline & & $\mathrm{R}^{2}$ & $\mathrm{~B}$ & $\mathrm{SE}$ & $\beta$ & $\mathrm{t}$ & $\mathrm{p}$ \\
\hline 1 & Machiavellianism & .16 & .42 & .07 & .41 & 6.24 & .00 \\
2 & Narcissism & .10 & .31 & .07 & .31 & 4.65 & .00 \\
3 & Psychopathy & .13 & .46 & .08 & .37 & 5.51 & .00 \\
\hline
\end{tabular}

It is observed that Machiavellianism is responsible for $16 \%$ of the variation of counterproductive work behavior, the regression equation being statistically significant, $F(1,198)$ $=38.93, p<.01$. Machiavellian is significantly and positively associated with counterproductive work behavior, $\beta=.41, p$ $<.01$.

Narcissism is responsible for $10 \%$ of the variation of counterproductive work behavior, the regression equation being statistically significant, $F(1,198)=21.60, p<.01$. Narcissism is significantly and positively associated with counterproductive work behavior, $\beta=.31, p<.01$.

Psychopathy is responsible for $13 \%$ of the variation of counterproductive work behavior, the regression equation being statistically significant, $F(1,198)=30.36, p<.01$. Psychopathy is significantly and positively associated with counterproductive work behavior, $\beta=.37, p<.01$. 
H4: Risk-taking mediates the relationship between accentuated personality traits (Machiavellianism, narcissism, psychipathy) and counterproductive work behavior.

In order to test this hypothesis, three mediation analyzes were performed having as predictors, alternatively,
Machiavellianism, psychopathy and narcissism, as a dependent variable counterproductive work behavior and as a mediating variable, risk-taking.

Table 14. Mediation estimates for risk-taking in the relationship between Machiavellianism and counterproductive work behavior

\begin{tabular}{|c|c|c|c|c|c|c|c|c|}
\hline \multirow[b]{2}{*}{ Effect } & \multirow[b]{2}{*}{ Label } & \multirow[b]{2}{*}{ Estimation } & \multirow[b]{2}{*}{ SE } & \multicolumn{2}{|c|}{ 95\% Confidence Interval } & \multirow[b]{2}{*}{ Z } & \multirow[b]{2}{*}{$p$} & \multirow[b]{2}{*}{$\%$ Mediation } \\
\hline & & & & Lower & Upper & & & \\
\hline Indirect & $a \times b$ & .07 & .03 & .02 & .13 & 2.46 & .01 & 17.6 \\
\hline Direct & c & .34 & .07 & .21 & .48 & 4.86 & $<.00$ & 82.4 \\
\hline Total & $c+a \times b$ & .42 & .07 & .29 & .55 & 6.27 & $<.00$ & 100.0 \\
\hline
\end{tabular}

Table 15. Path analysis for risk-taking in the relationship between Machiavellianism and counterproductive work behavior

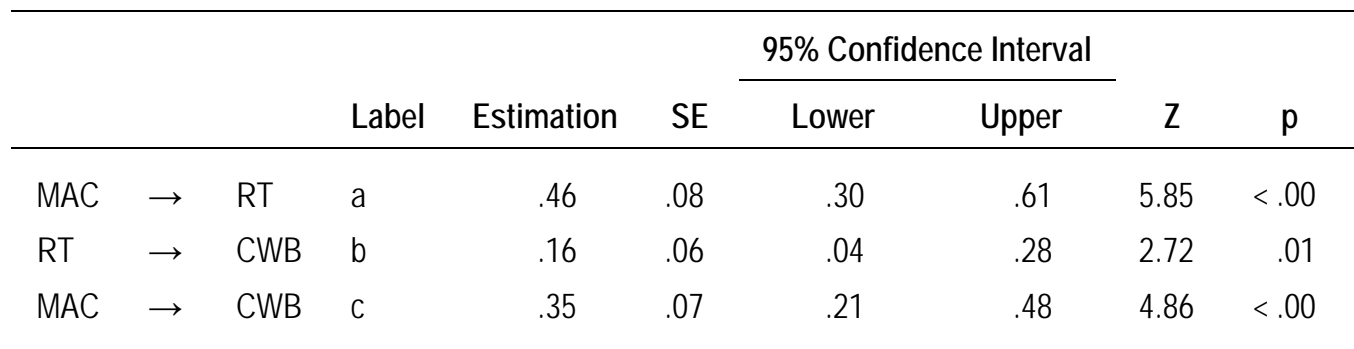

MAC - Machiavellianism, RT - Risk-taking, CWB - Counterproductive work behavior

Table 16. Mediation estimates for risk-taking in the relationship between psychopathy and counterproductive work behavior

\begin{tabular}{|c|c|c|c|c|c|c|c|c|}
\hline \multirow[b]{2}{*}{ Effect } & \multirow[b]{2}{*}{ Label } & \multirow[b]{2}{*}{ Estimation } & \multirow[b]{2}{*}{ SE } & \multicolumn{2}{|c|}{ 95\% Confidence Interval } & \multirow[b]{2}{*}{ Z } & \multirow[b]{2}{*}{$p$} & \multirow[b]{2}{*}{$\%$ Mediation } \\
\hline & & & & Lower & Upper & & & \\
\hline Indirect & $a \times b$ & .10 & .04 & .02 & .18 & 2.55 & .01 & 22.4 \\
\hline Direct & c & .36 & .09 & .18 & .53 & 3.98 & $<.00$ & 77.6 \\
\hline Total & $c+a \times b$ & .46 & .08 & .30 & .62 & 5.54 & $<.00$ & 100.0 \\
\hline
\end{tabular}

Table 17. Path analysis for risk-taking in the relationship between psychopathy and counterproductive work behavior

\begin{tabular}{|c|c|c|c|c|c|c|c|c|c|}
\hline & & & \multirow[b]{2}{*}{ Label } & \multirow[b]{2}{*}{ Estimation } & \multirow[b]{2}{*}{ SE } & \multicolumn{2}{|c|}{ 95\% Confidence Interval } & \multirow[b]{2}{*}{ z } & \multirow[b]{2}{*}{$p$} \\
\hline & & & & & & Lower & Upper & & \\
\hline PSI & $\rightarrow$ & RT & a & .61 & .09 & .42 & .79 & 6.45 & $<.00$ \\
\hline RT & $\rightarrow$ & CWB & $\mathrm{b}$ & .17 & .06 & .05 & .29 & 2.77 & .01 \\
\hline PSI & $\rightarrow$ & CWB & c & .36 & .09 & .18 & .53 & 3.98 & $<.00$ \\
\hline
\end{tabular}

PSI - Psychopathy, RT - Risk-taking, CWB - Counterproductive work behavior 
Table 18. Mediation estimates for risk-taking in the relationship between narcissism and counterproductive work behavior

\begin{tabular}{|c|c|c|c|c|c|c|c|c|}
\hline \multirow[b]{2}{*}{ Effect } & \multirow[b]{2}{*}{ Label } & \multirow[b]{2}{*}{ Estimation } & \multirow[b]{2}{*}{ SE } & \multicolumn{2}{|c|}{ 95\% Confidence Interval } & \multirow[b]{2}{*}{ Z } & \multirow[b]{2}{*}{$\mathrm{p}$} & \multirow[b]{2}{*}{$\%$ Mediation } \\
\hline & & & & Lower & Upper & & & \\
\hline Indirect & $a \times b$ & .06 & .02 & .01 & .11 & 2.56 & .01 & 19.2 \\
\hline Direct & c & .25 & .07 & .12 & .38 & 3.80 & $<.00$ & 80.8 \\
\hline Total & $c+a \times b$ & .31 & .07 & .18 & .45 & 4.67 & $<.00$ & 100.0 \\
\hline
\end{tabular}

Table 19. Path analysis for risk-taking in the relationship between narcissism and counterproductive work behavior

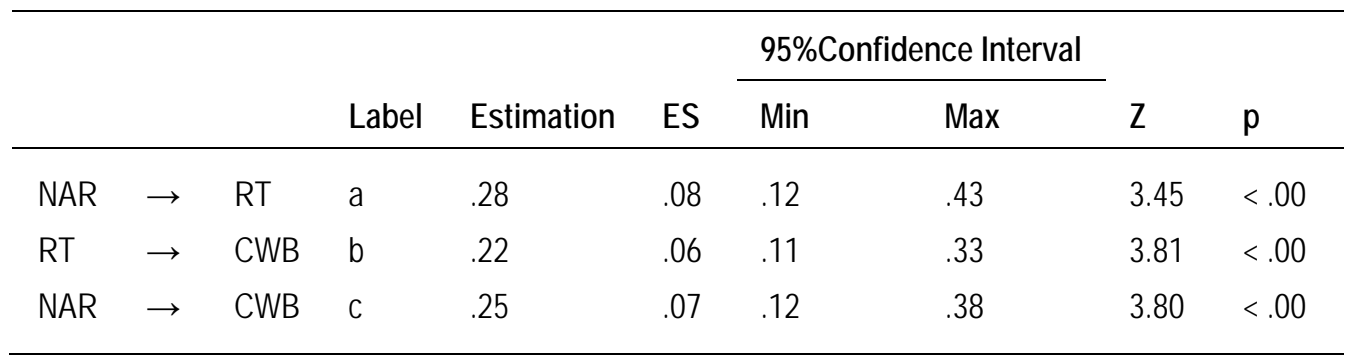

NAR - Narcissism, RT - Risk-taking, CWB - Counterproductive work behavior

It is observed that risk-taking mediates the relationship between Machiavellianism and counterproductive work behavior, the mediation percentage being $17.6 \%$, and the mediation estimate $\beta=.07, \mathrm{Cl} 95 \%$ (. 02, .13), $Z=2.46, p<$ .05 . Machiavellianism is positively associated with risktaking, $\beta=.46, \mathrm{Cl} 95 \%(.30, .61), \mathrm{Z}=5.85, \mathrm{p}<.00$ and risktaking is positively associated with counterproductive work behavior, $\beta=.16, \mathrm{Cl} 95 \%(.04, .28), Z=2.72, p<.05$.

Also risk-taking mediates the relationship between psychopathy and counterproductive work behavior, the mediation percentage being $22.4 \%$, and the mediation estimate $\beta=.10, \mathrm{Cl} 195 \%$ (.02, .18), $Z=2.55, p<.05$.

\section{DISCUSSION}

The present study aimed to analyze the relationship between accentuated personality traits (Dark Triad) and counterproductive behavior in the workplace, as well as the impact of risk-taking on this relationship. A comprehensive analysis was also performed that integrates sociodemographic variables such as type of organization (profit or non-profit), seniority and position in the organization (executive or leadership). These have been studied in relation to risk-taking and counterproductive behavior in the workplace.

Emphasis was placed on the effect that risk-taking has on the relationship between dark personality traits and counterproductive behavior in the workplace. Thus, it was observed that risk-taking mediates to a large extent (22.4\%) the relationship between psychopathy and negative behaviors that employees may have at work, whether in a corporation or in a non-governmental organization. This
Psychopathy is positively associated with risk-taking, $\beta=$ $.61, \mathrm{Cl} 95 \%(.42, .79), \mathrm{Z}=6.45, \mathrm{p}<.00$ and risk-taking is positively associated with counterproductive work behavior, $\beta=.17, \mathrm{Cl} 195 \%(.05, .29), Z=2.77, p<.05$.

At the same time, risk-taking mediates the relationship between narcissism and counterproductive work behavior, the mediation percentage being $19.2 \%$, and the mediation estimate $\beta=.06, \mathrm{Cl} 195 \%(.01, .11), Z=2.56, p<.05$. Narcissism is positively associated with risk-taking, $\beta=.28$, CI95\% (.12, .43), $Z=3.45, p<.00$ and risk-taking is positively associated with counterproductive work behavior, $\beta=.22$, Cl95\% (.11, .33), Z = 3.81, $p<.00$.

characteristic is positively associated with both risk-taking and counterproductive behavior. The relationship can be explained by traits such as impulsivity, specific to psychopathy (Miller \& Lynam, 2012), which in turn leads to risk-taking and, later, to undesirable actions at work. Narcissism occupies the second position, the mediation percentage being $19.2 \%$. Similar to psychopathy, it is positively associated with the two factors mentioned above. People with this trait tend to believe that the rules do not apply to them, so it is easy for them not to follow them, taking risks. Last but not least, it has been shown that risk-taking mediates the relationship between Machiavellianism and counterproductive behavior at work to the extent of almost 18 percent (17.6\%).

Numerous previous studies have theoretically tested the relationship between the Dark Triad and counterproductive behavior in the workplace. However, it is uncertain whether 
the effect is direct or rather indirect, built on other factors. Spain et al. (2014) concluded that these characteristics are useful in explaining various behaviors at work, some being desirable and others not. Another study by James et al. (2014), focused on the direct effects of this relationship. They have demonstrated that all three facets of the Dark Triad correlate directly with a high level of pleasure derived from another person's misfortune. Specifically, individuals who have strong personality traits express increased satisfaction when a colleague receives negative feedback about his or her performance. These findings provide insight into the direct practical implications of the features of the Dark Triad in the workplace, highlighting the consequences that may arise. Also, following a meta-analysis, O'Boyle et al. (2012) observed that all three accentuated personality traits are strongly associated with counterproductive behavior in the workplace.

Regarding the influence of risk-taking on the relationship between the two variables, no comprehensive studies have been found in the literature to focus on it, being a gap that this paper wants to cover. The results of the study by Grover and Furnham (2021) state that there is a link between risktaking and two of the accentuated personality traits, namely psychopathy and narcissism, but there are no works that consider the relationship between this variable and counterproductive behavior in place. for work.

Hypothesis $\mathrm{H} 1$ showed that there are significant differences in risk-taking depending on different sociodemographic variables. Thus, it was observed that people who work in non-profit organizations assume more risks, as well as those who have a low seniority in work or hold a management position. These behaviors can be explained by the rewards received or by the importance of possible losses, in the case of a job the rewards being financial, while in the case of volunteering (NGO), no. Also, the risks taken may decrease with seniority due to both aging and the desire for stability. Last but not least, a leading position within the organization puts the person in a position to make many decisions and, through them, to take more risks. The results are consistent with previous studies, however there is little evidence of how material reward affects people's decision to take risks or not (Ittner \& Larcker, 2001) and further leads to the difference between nonprofits and places. stable work. Moreover, (García-Granero et al. (2015) state that people in management positions take more risks out of the desire to innovate.

The variation of the counterproductive behavior at work according to the type of organization, the position occupied within it and the seniority in work $(\mathrm{H} 2)$ was also researched. Although no significant difference was observed in terms of the first two demographic characteristics, the behavior adopted at work and seniority are closely related. This can be due to several factors, such as increased emotional stability (Williams et al., 2006) or decreased frustration and desire for revenge (Penney et al., 2011). A multitude of previous studies have similar results. For example, Barefoot et al. (1993) observed that older people have a lower level of anger and hostility towards those around them. Other studies have found that such people have greater emotional intelligence, regulating their emotions more easily (Chapman \& Hayslip Jr., 2006; Siu et al., 2001). Together, such studies suggest that in the case of older people, counterproductive behavior tends to decrease rather. Regarding the type of organization, while some studies claim that people satisfied with the amount of money received engage in fewer counterproductive behaviors (Lawal et al., 2019), the present research does not show a significant difference between the two types. of organizations. Thus, people who volunteer may have a desirable behavior due to interest in the field (Cheasakul \& Varma, 2016). Also, according to the results obtained, the high position, such as manager, occupied within the organization is not closely related to counterproductive behavior at work. This relationship can be explained by the fact that people in management tend to be more attached to the job, with less desire to take revenge or sabotage the organization. One of the reasons behind the attachment to the workplace may be the road or effort made to the position currently held, as well as the resources invested (Stroh \& Brett, 1994).

\section{Limitations and further research}

One of the limitations of the study refers to the application of self-reporting tools to measure risk-taking, counterproductive behavior in the workplace and accentuated personality traits. The response of the persons concerned can often be subjective, with the possibility that they may respond as they deem socially desirable, despite the anonymity of the form, or even not recognize certain traits for themselves. In the future, the collection of data from several sources may be considered, so as to increase the validity of the study. However, self-reporting tools are often encountered in similar studies (e.g. Jonason et al., 2012; Palmer et al., 2017).

Another limitation of this study is the composition of the group of respondents, which is made up of $82.5 \%$ of females. Thus, the generalization of the results must be done with caution, also taking into account the fact that the respondent population belongs to a single country and falls mostly in the category of young people, aged between 18 and 25 years. The small number of men participating in the study did not make it possible to perform a comparative analysis by gender, but comparisons were made based on other socio-cultural variables, such as seniority and function. Therefore, for the following studies, emphasis can be placed on the diversity of respondents, both by gender and age.

In addition, the study performed is a cross-sectional one, thus failing to highlight clearly enough the causal aspects of 
the relationship studied. A longitudinal study can better shed light on the causal relationship between accentuated personality traits and counterproductive behavior in the workplace.

In the future, in addition to the changes mentioned above, the importance of job satisfaction can be explored,

\section{REFERENCES}

Alavi, M., Kye Mei, T., \& Mehrinezhad, S. A. (2018). The Dark Triad of personality and infidelity intentions: The moderating role of relationship experience. Personality and Individual Differences, 128, 49-54. https://doi.org/10.1016/j.paid.2018.02.023

Ali, A., \& Akram, M. N. (2012). Impact of Financial Rewards on Employee's Motivation and Satisfaction in Pharmaceutical Industry, Pakistan. 7.

Ames, D. (2009). Pushing up to a point: Assertiveness and effectiveness in leadership and interpersonal dynamics. Research in Organizational Behavior - RES ORGAN BEH, 29, 111-133. https://doi.org/10.1016/j.riob.2009.06.010

Ashton, M. C., \& Lee, K. (2016). Age trends in HEXACO-PIR self-reports. Journal of Research in Personality, 64, 102111. https://doi.org/10.1016/j.jrp.2016.08.008

Azizli, N., Atkinson, B. E., Baughman, H. M., Chin, K., Vernon, P. A., Harris, E., \& Veselka, L. (2016). Lies and crimes: Dark Triad, misconduct, and high-stakes deception. Personality and Individual Differences, 89, 34-39. https://doi.org/10.1016/j.paid.2015.09.034

Baloch, M. A., Meng, F., Xu, Z., Cepeda-Carrion, I., Danish, \& Bari, M. W. (2017). Dark Triad, Perceptions of Organizational Politics and Counterproductive Work Behaviors: The Moderating Effect of Political Skills. Frontiers in Psychology, 8. https://doi.org/10.3389/fpsyg.2017.01972 Barefoot, J. C., Beckham, J. C., Haney, T. L., Siegler, I. C., \& Lipkus, I. M. (1993). Age differences in hostility among middle-aged and older adults. Psychology and Aging, 8(1), 3-9. https://doi.org/10.1037/0882-7974.8.1.3

Bender, D. S. (2012). Mirror, Mirror on the Wall: Reflecting on Narcissism. Journal of Clinical Psychology, 68(8), 877885. https://doi.org/10.1002/jclp.21892

Bennett, R. J., \& Robinson, S. L. (2000). Development of a measure of workplace deviance. Journal of Applied Psychology, 85(3), 349-360. https://doi.org/10.1037/00219010.85.3.349

Berry, C. M., Carpenter, N. C., \& Barratt, C. L. (2012). Do other-reports of counterproductive work behavior provide an incremental contribution over self-reports? A meta-analytic comparison. Journal of Applied Psychology, 97(3), 613636. https://doi.org/10.1037/a0026739

Berry, C. M., Ones, D. S., \& Sackett, P. R. (2007). Interpersonal deviance, organizational deviance, and their common correlates: A review and meta-analysis. Journal of as well as the link between it and counterproductive behavior. Moreover, the difference between the male and female gender in terms of such behaviors can be observed, being a useful information for employers. Through several studies in this field, they can better understand the reasons for absenteeism or lack of productivity at work.
Applied Psychology, 92(2), 410-424. https://doi.org/10.1037/0021-9010.92.2.410

Blais, A.-R., \& Weber, E. U. (2006). A Domain-Specific RiskTaking (DOSPERT) scale for adult populations. Judgment and Decision Making, 1(1), 15.

Board, B. J., \& Fritzon, K. (2005). Disordered personalities at work. Psychology, Crime \& Law, 11(1), 17-32. https://doi.org/10.1080/10683160310001634304

Bolino, M. C., \& Turnley, W. H. (2003). More Than One Way to Make an Impression: Exploring Profiles of Impression Management. Journal of Management, 29(2), 141-160. https://doi.org/10.1177/014920630302900202

Brewer, G., De Griffa, D., \& Uzun, E. (2019). Dark triad traits and women's use of sexual deception. Personality and Individual Differences, 142, 42-44. https://doi.org/10.1016/j.paid.2019.01.033

Buelow, M. T., \& Brunell, A. B. (2014). Facets of grandiose narcissism predict involvement in health-risk behaviors. Personality and Individual Differences, 69, 193-198. https://doi.org/10.1016/j.paid.2014.05.031

Buffardi, L. E., \& Campbell, W. K. (2008). Narcissism and Social Networking Web Sites. Personality and Social Psychology Bulletin, 34(10), 1303-1314. https://doi.org/10.1177/0146167208320061

Campbell, J. P. (1990). Modeling the performance prediction problem in industrial and organizational psychology. In Handbook of industrial and organizational psychology, Vol. 1, 2nd ed (pp. 687-732). Consulting Psychologists Press.

Cauffman, E., \& Steinberg, L. (2000). Researching adolescents' judgment and culpability. In Youth on trial: $A$ developmental perspective on juvenile justice (pp. 325343). University of Chicago Press.

Chabrol, H., Bouvet, R., \& Goutaudier, N. (2017). The Dark Tetrad and Antisocial Behavior in a Community Sample of College Students. Journal of Forensic Psychology Research and Practice, 17(5), 295-304. https://doi.org/10.1080/24732850.2017.1361310

Chapman, B. P., \& Hayslip Jr., B. (2006). Emotional intelligence in young and middle adulthood: Cross-sectional analysis of latent structure and means. Psychology and Aging, 21(2), 411-418. https://doi.org/10.1037/08827974.21.2.411

Cheasakul, U., \& Varma, P. (2016). The influence of passion and empowerment on organizational citizenship behavior of teachers mediated by organizational commitment. 
Contaduría y Administración, 61(3), 422-440. https://doi.org/10.1016/j.cya.2016.04.003

Cohen, A. (2016). Are they among us? A conceptual framework of the relationship between the dark triad personality and counterproductive work behaviors (CWBs). Human Resource Management Review, 26(1), 69-85. https://doi.org/10.1016/j.hrmr.2015.07.003

Cox, J. A., \& Hetzel, A. J. (2008). Uniformly primary ideals. Journal of Pure and Applied Algebra, 212(1), 1-8. https://doi.org/10.1016/j.jpaa.2007.03.007

Crysel, L. C., Crosier, B. S., \& Webster, G. D. (2013). The Dark Triad and risk behavior. Personality and Individual Differences, 54(1), 35-40. https://doi.org/10.1016/j.paid.2012.07.029

DeShong, H. L., Grant, D. M., \& Mullins-Sweatt, S. N. (2015). Comparing models of counterproductive workplace behaviors: The Five-Factor Model and the Dark Triad. Personality and Individual Differences, 74, 55-60. https://doi.org/10.1016/j.paid.2014.10.001

Edmonds, E., \& Shrestha, M. (2012). The Impact of Minimum Age of Employment Regulation on Child Labor and Schooling: Evidence from UNICEF MICS Countries (No. w18623; p. w18623). National Bureau of Economic Research. https://doi.org/10.3386/w18623

Farwell, L., \& Wohlwend-Lloyd, R. (1998). Narcissistic Processes: Optimistic Expectations, Favorable SelfEvaluations, and Self-Enhancing Attributions. Journal of Personality, 66(1), 65-83. https://doi.org/10.1111/14676494.00003

Figner, B., \& Weber, E. U. (2011). Who Takes Risks When and Why?: Determinants of Risk Taking. Current Directions in Psychological Science, 20(4), 211-216. https://doi.org/10.1177/0963721411415790

Fischhoff, B. (1992). Risk taking: A developmental perspective. In Risk-taking behavior (pp. 133-162). John Wiley \& Sons.

Foster, J. D., Reidy, D. E., Misra, T. A., \& Goff, J. S. (2011). Narcissism and stock market investing: Correlates and consequences of cocksure investing. Personality and Individual Differences, 50(6), 816-821. https://doi.org/10.1016/j.paid.2011.01.002

Gabriel, M. T., Critelli, J. W., \& Ee, J. S. (1994). Narcissistic illusions in self-evaluations of intelligence and attractiveness. Journal of Personality, 62(1), 143-155. https://doi.org/10.1111/j.1467-6494.1994.tb00798.x

García-Granero, A., Llopis, Ó., Fernández-Mesa, A., \& Alegre, J. (2015). Unraveling the link between managerial risk-taking and innovation: The mediating role of a risktaking climate. Journal of Business Research, 68(5), 10941104. https://doi.org/10.1016/j.jbusres.2014.10.012

Gardner, M., \& Steinberg, L. (2005). Peer Influence on Risk Taking, Risk Preference, and Risky Decision Making in Adolescence and Adulthood: An Experimental Study.
Developmental Psychology, 41(4), 625-635. https://doi.org/10.1037/0012-1649.41.4.625

Gott, A. J., \& Hetzel-Riggin, M. D. (2018). What Did You Expect? Substance Use Expectancies Mediate the Relationships Between Dark Triad Traits, Substance Use, and Substance Preference. Psychological Reports, 121(5), 831-852. https://doi.org/10.1177/0033294118755094

Grover, S., \& Furnham, A. (2021). The moderating effects of emotional stability on the relationship between the Dark Triad and different measures of risk-taking. Personality and Individual Differences, 171, 110450. https://doi.org/10.1016/j.paid.2020.110450

Hare, R. D., \& Neumann, C. S. (2008). Psychopathy as a Clinical and Empirical Construct. Annual Review of Clinical Psychology, 4(1), 217-246. https://doi.org/10.1146/annurev.clinpsy.3.022806.091452 Harpur, T. J., Hare, R. D., \& Hakstian, A. R. (1989). Twofactor conceptualization of psychopathy: Construct validity and assessment implications. Psychological Assessment: A Journal of Consulting and Clinical Psychology, 1(1), 6-17. https://doi.org/10.1037/1040-3590.1.1.6

Hart, S. D., \& Hare, R. D. (1997). Psychopathy: Assessment and association with criminal conduct. In Handbook of antisocial behavior (pp. 22-35). John Wiley \& Sons Inc.

Hemphill, J. F., Hare, R. D., \& Wong, S. (1998). Psychopathy and recidivism: A review. Legal and Criminological Psychology, 3(Part 13), 170. https://doi.org/10.1111/j.2044-8333.1998.tb00355.x

Hollinger, R. C., \& Davis, J. L. (2001). 2001 NATIONAL RETAIL SECURITY SURVEY. 13.

Irwin, C. E., \& Ryan, S. A. (1989). Problem behavior of adolescents. Pediatrics in Review, 10(8), 235-246. https://doi.org/10.1542/pir.10-8-235

Ittner, C. D., \& Larcker, D. F. (2001). Assessing empirical research in managerial accounting: $A$ value-based management perspective. Journal of Accounting and Economics, 32(1), 349-410. https://doi.org/10.1016/S01654101(01)00026-X

James, S., Kavanagh, P. S., Jonason, P. K., Chonody, J. M., \& Scrutton, H. E. (2014). The Dark Triad, schadenfreude, and sensational interests: Dark personalities, dark emotions, and dark behaviors. Personality and Individual Differences, $68, \quad 211-216$. https://doi.org/10.1016/j.paid.2014.04.020

Jonason, P. K., Koehn, M. A., Okan, C., \& O'Connor, P. J. (2018). The role of personality in individual differences in yearly earnings. Personality and Individual Differences, 121, 170-172. https://doi.org/10.1016/j.paid.2017.09.038 JONASON, P. K., LI, N. P., \& TEICHER, E. A. (2010). Who is James Bond? The Dark Triad as an Agentic Social Style. Individual Differences Research, 8(2), 111-120.

Jonason, P. K., Li, N. P., Webster, G. D., \& Schmitt, D. P. (2009). The dark triad: Facilitating a short-term mating 
strategy in men. European Journal of Personality, 23(1), 518. https://doi.org/10.1002/per.698

Jonason, P. K., \& Schmitt, D. P. (2012). What Have You Done for Me Lately? Friendship-Selection in the Shadow of the Dark Triad Traits. Evolutionary Psychology, 10(3), 147470491201000.

https://doi.org/10.1177/147470491201000303

Jonason, P. K., Slomski, S., \& Partyka, J. (2012). The Dark

Triad at work: How toxic employees get their way. Personality and Individual Differences, 52(3), 449-453. https://doi.org/10.1016/j.paid.2011.11.008

Jonason, P., Li, N., \& Teicher, E. (2010). Who is James Bond? The Dark Triad as an Agentic Social Style. Individual Differences Research, 8.

Jones, Daniel N. (2013a). Psychopathy and machiavellianism predict differences in racially motivated attitudes and their affiliations: Dark Triad and racism. Journal of Applied Social Psychology, 43, E367-E378. https://doi.org/10.1111/jasp.12035

Jones, Daniel N. (2013b). What's mine is mine and what's yours is mine: The Dark Triad and gambling with your neighbor's money. Journal of Research in Personality, 47(5), 563-571. https://doi.org/10.1016/j.jp.2013.04.005 Jones, Daniel N., \& Paulhus, D. L. (2011). The role of impulsivity in the Dark Triad of personality. Personality and Individual Differences, 51(5), 679-682. https://doi.org/10.1016/j.paid.2011.04.011

Jones, Daniel Nelson, \& Figueredo, A. J. (2013). The Core of Darkness: Uncovering the Heart of the Dark Triad. European Journal of Personality, 27(6), 521-531. https://doi.org/10.1002/per.1893

Judge, T. A., LePine, J. A., \& Rich, B. L. (2006). Loving yourself abundantly: Relationship of the narcissistic personality to self- and other perceptions of workplace deviance, leadership, and task and contextual performance. Journal of Applied Psychology, 91(4), 762-776. https://doi.org/10.1037/0021-9010.91.4.762

Kavanagh, P. S., Signal, T. D., \& Taylor, N. (2013). The Dark Triad and animal cruelty: Dark personalities, dark attitudes, and dark behaviors. Personality and Individual Differences, 55(6), 666-670. https://doi.org/10.1016/j.paid.2013.05.019 Lakey, C. E., Rose, P., Campbell, W. K., \& Goodie, A. S. (2008). Probing the link between narcissism and gambling: The mediating role of judgment and decision-making biases. Journal of Behavioral Decision Making, 21(2), 113-137. https://doi.org/10.1002/bdm.582

Lawal, A., Babalola, S., \& Ordu, U. (2019). Examining Age, Pay Satisfaction and Intent to Leave in Counterproductive Work Behaviour among University Support Staff *

Leather, N. C. (2009). Risk-taking behaviour in adolescence: A literature review. Journal of Child Health Care, 13(3), 295304. https://doi.org/10.1177/1367493509337443

McCleskey, J., \& Gruda, D. (2020). Risk-taking, resilience, and state anxiety during the COVID-19 pandemic: A coming of (old) age story. Personality and Individual Differences, 110485. https://doi.org/10.1016/j.paid.2020.110485

Miller, J. D., \& Campbell, W. K. (2008). Comparing Clinical and Social-Personality Conceptualizations of Narcissism. Journal of Personality, 76(3), 449-476. https://doi.org/10.1111/j.1467-6494.2008.00492.x

Miller, J. D., \& Lynam, D. R. (2012). An examination of the Psychopathic Personality Inventory's nomological network: A meta-analytic review. Personality Disorders: Theory, Research, and Treatment, 3(3), 305-326. https://doi.org/10.1037/a0024567

Moore, C., Detert, J. R., Klebe Treviño, L., Baker, V. L., \& Mayer, D. M. (2012). WHY EMPLOYEES DO BAD THINGS: MORAL DISENGAGEMENT AND UNETHICAL ORGANIZATIONAL BEHAVIOR: PERSONNEL PSYCHOLOGY. Personnel Psychology, 65(1), 1-48. https://doi.org/10.1111/j.1744-6570.2011.01237.x

Morf, C. C., \& Rhodewalt, F. (2001). Unraveling the paradoxes of narcissism: A dynamic self-regulatory processing model. Psychological Inquiry, 12(4), 177-196. https://doi.org/10.1207/S15327965PLI1204_1

Muris, P., Merckelbach, H., Otgaar, H., \& Meijer, E. (2017). The Malevolent Side of Human Nature: A Meta-Analysis and Critical Review of the Literature on the Dark Triad (Narcissism, Machiavellianism, and Psychopathy). Perspectives on Psychological Science, 12(2), 183-204. https://doi.org/10.1177/1745691616666070

Nathan DeWall, C., Buffardi, L. E., Bonser, I., \& Keith Campbell, W. (2011). Narcissism and implicit attention seeking: Evidence from linguistic analyses of social networking and online presentation. Personality and Individual Differences, 51(1), 57-62. https://doi.org/10.1016/j.paid.2011.03.011

Nevicka, Barbara, Van Vianen, A. E. M., De Hoogh, A. H. B., \& Voorn, B. C. M. (2018). Narcissistic leaders: An asset or a liability? Leader visibility, follower responses, and grouplevel absenteeism. The Journal of Applied Psychology, 103(7), 703-723. https://doi.org/10.1037/apl0000298

Nevicka, Barbora, De Hoogh, A. H. B., Van Vianen, A. E. M., Beersma, B., \& Mcllwain, D. (2011). All I need is a stage to shine: Narcissists' leader emergence and performance. The Leadership Quarterly, 22(5), 910-925. https://doi.org/10.1016/j.leaqua.2011.07.011

$\mathrm{Ng}, \mathrm{T}$. W. H., \& Feldman, D. C. (2008). The relationship of age to ten dimensions of job performance. Journal of Applied Psychology, 93(2), 392-423. https://doi.org/10.1037/0021-9010.93.2.392

Nguyen, N., Pascart, S., \& Borteyrou, X. (2021). The dark triad personality traits and work behaviors: A personcentered approach. Personality and Individual Differences, 170, 110432. https://doi.org/10.1016/j.paid.2020.110432 O'Boyle, E. H., Forsyth, D. R., Banks, G. C., \& McDaniel, M. A. (2012). A meta-analysis of the Dark Triad and work behavior: A social exchange perspective. Journal of Applied 
Psychology, 97(3),

$557-579$.

https://doi.org/10.1037/a0025679

O'Boyle, E. H., Forsyth, D. R., \& O'Boyle, A. S. (2011). Bad Apples or Bad Barrels: An Examination of Group- and Organizational-Level Effects in the Study of Counterproductive Work Behavior. Group \& Organization Management, 36(1), 39-69. https://doi.org/10.1177/1059601110390998

O'Brien, K. E., \& Allen, T. D. (2007). The Relative Importance of Correlates of Organizational Citizenship Behavior and Counterproductive Work Behavior Using Multiple Sources of Data. Human Performance, 21(1), 6288. https://doi.org/10.1080/08959280701522189

O'Neill, T. A., \& Hastings, S. E. (2011). Explaining workplace deviance behavior with more than just the "Big Five." Personality and Individual Differences, 50(2), 268-273. https://doi.org/10.1016/j.paid.2010.10.001

Palmer, J. C., Komarraju, M., Carter, M. Z., \& Karau, S. J. (2017). Angel on one shoulder: Can perceived organizational support moderate the relationship between the Dark Triad traits and counterproductive work behavior? Personality and Individual Differences, 110, 31-37. https://doi.org/10.1016/j.paid.2017.01.018

Paulhus, D. L. (1998). Interpersonal and intrapsychic adaptiveness of trait self-enhancement: A mixed blessing? Journal of Personality and Social Psychology, 74(5), 11971208. https://doi.org/10.1037/0022-3514.74.5.1197

Paulhus, D. L. (2014). Toward a Taxonomy of Dark Personalities. Current Directions in Psychological Science, 23(6), 421-426. https://doi.org/10.1177/0963721414547737

Paulhus, D. L., \& Williams, K. M. (2002). The Dark Triad of personality: Narcissism, Machiavellianism, and psychopathy. Journal of Research in Personality, 36(6), 556-563. https://doi.org/10.1016/S0092-6566(02)00505-6

Penney, L. M., Hunter, E. M., \& Perry, S. J. (2011). Personality and counterproductive work behaviour: Using conservation of resources theory to narrow the profile of deviant employees: Personality and CWB. Journal of Occupational and Organizational Psychology, 84(1), 58-77. https://doi.org/10.1111/j.2044-8325.2010.02007.x

Pletzer, J. L. (2021). Why older employees engage in less counterproductive work behavior and in more organizational citizenship behavior: Examining the role of the HEXACO personality traits. Personality and Individual Differences, 173, 110550. https://doi.org/10.1016/j.paid.2020.110550

Rauthmann, J. F. (2012). The Dark Triad and Interpersonal Perception: Similarities and Differences in the Social Consequences of Narcissism, Machiavellianism, and Psychopathy. Social Psychological and Personality Science, $\quad 3(4), \quad$ 487-496. https://doi.org/10.1177/1948550611427608

Rauthmann, J. F., \& Will, T. (2011). Proposing a Multidimensional Machiavellianism Conceptualization.
Social Behavior and Personality: An International Journal, 39(3), 391-403. https://doi.org/10.2224/sbp.2011.39.3.391 Ruiz-Palomino, P., \& Linuesa-Langreo, J. (2018). Implications of person-situation interactions for Machiavellians' unethical tendencies: The buffering role of managerial ethical leadership. European Management Journal, 36(2), 243-253. https://doi.org/10.1016/j.emj.2018.01.004

Sackett, P. R., \& DeVore, C. J. (2002). Counterproductive behaviors at work. In Handbook of industrial, work and organizational psychology, Volume 1: Personnel psychology (pp. 145-164). Sage Publications Ltd.

Sawyer, S. M., Azzopardi, P. S., Wickremarathne, D., \& Patton, G. C. (2018). The age of adolescence. The Lancet Child \& Adolescent Health, 2(3), 223-228. https://doi.org/10.1016/S2352-4642(18)30022-1

Scherer, K. T., Baysinger, M., Zolynsky, D., \& LeBreton, J. M. (2013). Predicting counterproductive work behaviors with sub-clinical psychopathy: Beyond the Five Factor Model of personality. Personality and Individual Differences, 55(3), 300-305. https://doi.org/10.1016/j.paid.2013.03.007

Schonberg, T., Fox, C. R., \& Poldrack, R. A. (2011). Mind the Gap: Bridging economic and naturalistic risk-taking with cognitive neuroscience. Trends in Cognitive Sciences, 15(1), 11-19. https://doi.org/10.1016/j.tics.2010.10.002

Seidman, G. (2013). Self-presentation and belonging on Facebook: How personality influences social media use and motivations. Personality and Individual Differences, 54(3), 402-407. https://doi.org/10.1016/j.paid.2012.10.009

Shapira, Z. (1995). Risk taking: A managerial perspective. Russell Sage Foundation.

Siu, O., Cooper, C. L., Spector, P. E., \& Donald, I. (2001). Age differences in coping and locus of control: A study of managerial stress in Hong Kong. Psychology and Aging, 16(4), $\quad 707-710 . \quad$ https://doi.org/10.1037//08827974.16.4.707

Spain, S. M., Harms, P., \& LeBreton, J. M. (2014). The dark side of personality at work: DARK PERSONALITY REVIEW. Journal of Organizational Behavior, 35(S1), S41-S60. https://doi.org/10.1002/job.1894

Sprinkle, G. B., Williamson, M. G., \& Upton, D. R. (2008). The effort and risk-taking effects of budget-based contracts. Accounting, Organizations and Society, 33(4-5), 436-452. https://doi.org/10.1016/j.aos.2007.11.001

Stanwix, S., \& Walker, B. R. (2021). The Dark Tetrad and advantageous and disadvantageous risk-taking. Personality and Individual Differences, 168, 110338. https://doi.org/10.1016/j.paid.2020.110338

Stroh, L. K., \& Brett, J. M. (1994). A decade of change: Managers' attachment to their organizations and their jobs. Human Resource Management, 33(4), 531-548. https://doi.org/10.1002/hrm.3930330404

Veselka, L., Schermer, J. A., \& Vernon, P. A. (2012). The Dark Triad and an expanded framework of personality. 
Personality and Individual Differences, 53(4), 417-425. https://doi.org/10.1016/j.paid.2012.01.002

Vohs, K. D. (2015). Money priming can change people's thoughts, feelings, motivations, and behaviors: An update on 10 years of experiments. Journal of Experimental Psychology: General, 144(4), e86-e93. https://doi.org/10.1037/xge0000091

Volmer, J., Koch, I. K., \& Göritz, A. S. (2016). The bright and dark sides of leaders' dark triad traits: Effects on subordinates' career success and well-being. Personality and Individual Differences, 101, 413-418. https://doi.org/10.1016/j.paid.2016.06.046

Wilke, A., Sherman, A., Curdt, B., Mondal, S., Fitzgerald, C., \& Kruger, D. J. (2014). An evolutionary domain-specific risk scale. Evolutionary Behavioral Sciences, 8(3), 123-141. https://doi.org/10.1037/ebs0000011

Wu, J., \& Lebreton, J. M. (2011). RECONSIDERING THE DISPOSITIONAL BASIS OF COUNTERPRODUCTIVE WORK BEHAVIOR: THE ROLE OF ABERRANT PERSONALITY. Personnel Psychology, 64(3), 593-626. https://doi.org/10.1111/j.1744-6570.2011.01220.x

Zeigler-Hill, V., Besser, A., Morag, J., \& Keith Campbell, W. (2016). The Dark Triad and sexual harassment proclivity. Personality and Individual Differences, 89, 47-54. https://doi.org/10.1016/j.paid.2015.09.048

Zettler, I., \& Solga, M. (2013). Not Enough of a 'Dark' Trait? Linking Machiavellianism to Job Performance. European Journal of Personality, 27(6), 545-554. https://doi.org/10.1002/per.1912 